\title{
The Implementation Of Green Architecture In Music Center Building
}

\author{
Harisdani, D. D. 1 , Tantri, W' \\ 1,2 Jurusan Arsitektur, Fakultas Teknik, Universitas Sumatera Utara \\ Jl. Perpustakaan St. J07 Building, Medan, 20155, Indonesia \\ *Email: devin.defriza@usu.ac.id \\ Diterima: 29 Mei 2019 Direvisi: 30 Juni 2019 Online: 29 Juli 2019
}

\begin{abstract}
Green architecture can be implemented on the design of a music center building in Medan, Indonesia. The effectiveness of the studying process is related to the environment of the study places created through the implementation of green architecture into a natural, comfortable and tranquil environment both in and outside of the building. With this implementation, an energy-efficient building is designed which supports the development of the city's green area. To design the building itself, the architectural and non -architectural design stages are carried out by analyzing through various libraries and media as a consideration in solving design problems. The design of this building is related to the orientation of the building itself which utilizes natural lightning, attention to the direction of wind to create natural air circulation, provision of parking spaces and open spaces for convenience and the reuse of water resources which is a green architectural concept that is implemented in urban area's buildings.
\end{abstract}

Keywords: architecture, energy efficiency, green architecture, music center.

\section{INTRODUCTION}

The effectiveness of the studying process is related to the environment which is created through the implementation of green architecture into a natural, comfortable and tranquil environment both in and outside the building. The music industry is growing rapidly including Indonesia. Medan, which is one of the cities located in North Sumatera Province, Indonesia has many potential musicians. Although there are many music courses in this city, music courses which is based on the curriculum and is designed while paying attention to the environment condition are still hard to be found.

Based on the problems stated above, there's a need for a place that can facilitate and provide education about music where the concept of green architecture will be implemented in this building with the goal is to create a natural and comfortable environment for studying and to design an energy-efficient building in way of supporting the development of a green area.

\section{Function and Architectural Theory}

Music center is a place which accommodates studying activities about rhythm, songs, and harmony that can be created either by human's voice or musical instruments and even by both of them so that harmonious music can be produced (Poerwadarminta, 2008). The main function of this music center is for educational activities in the form of music learning both in vocal and musical instruments with other supporting functions like a hall or auditorium for a concert, etc. This music center is an informal educational place which is different from formal education found in schools in general. The education system that will be applied in this music center is adjusted to the curriculum by Yamaha Music Foundation from Japan.

Green architecture is an architectural concept that minimizes the consumption of natural resources, including energy, water, and materials, and has a less negative impact on the environment (Karyono, 2010). Some criteria that support the energy-efficient buildings are by minimizing the solar heat gain, paying attention to the orientation (by extending the orientation to East-West), spatial organization, maximizing the heat release, minimizing heat 
radiation, utilizing sunlight, optimizing the use of cross ventilation, the color and texture of buildings' exteriors, outer space design and utilizing renewable energy (Karyono, 2010).

The principles of green architecture are stated below : (a) Conserving Energy, the building must minimize the use of fuel or electrical energy and if possible maximize the use of natural energy around the building site, (b) Working with climate, designing a building must be based on the prevailing climate in the site and available energy sources, (c) Minimizing new resources, designing by optimizing the needs of new natural resources, so that these resources won't run out and can be used in the future / materials which are used should not be harmful to environment, (d) Respect for site, the building that will be built must not damage the original site conditions, so that if the building is not in used, the original site will not change and so will not change or damage the environment, (e) Respect for user, in designing a building, an architect must pay attention to all building users and meet all their needs (Vale \& Vale, 1991).

\section{Concept}

Green architecture deals with designing energy-efficient buildings. This design can be done in two ways which are passive and active. Passive design means designing by utilizing the energy that is available such as utilizing sunlight without the occurrence of overheating in the building due to the radiation from the sun itself, wind utilization for natural air circulation, etc. Whereas active design means designing by converting natural energy such as solar energy into electrical energy through solar panels (Karyono, 2004).

In addition to the concept stated above, the design of public spaces outside of the building such as parking space, park, circulation area, and green area is also needed to be considered. The design of public space relates to the activities of the users and functions, living space, friendly and humanist pedestrian and universal design which is thinking about the accessibility for people with disabilities (Darmawan, 2007).

Whereas in interior design, there are several aspects which must be considered as the standard of common space, user's behavior to the thermal comfort of the space. To create comfort in the use of the space, the design takes into account the minimum standard for each of the space function (Neufert \& Tjahjadi, 2002) and also the rooms which are needed for the building with music education function such as the auditorium, administrative offices, corridors of the classroom (Neufert \& Tjahjadi, 2002).

The condition of the study environment will affect the study process. By creating a comfortable environment, the effectiveness of the study process will increase. The behavior of male and female students are certainly different one another. Therefore the design must pay more attention to the influence of these behaviors to create a more positive learning environment (Magfirah \& Rachmawati, 2010)

Thermal comfort also needs to be considered in the process of designing inner space. By designing an inner space with good thermal conditions, artificial ventilation can be minimized. Ideal conditions that can be designed for the building to have thermal comfort can be by designing a roof with light color (to reflect light), designing the ventilation in such way as to allow cross ventilation, shading of the building, minimizing the direct illumination by the sun (can be by using materials that can reflect heat) (Figure 1) (Talarosha, 2005).

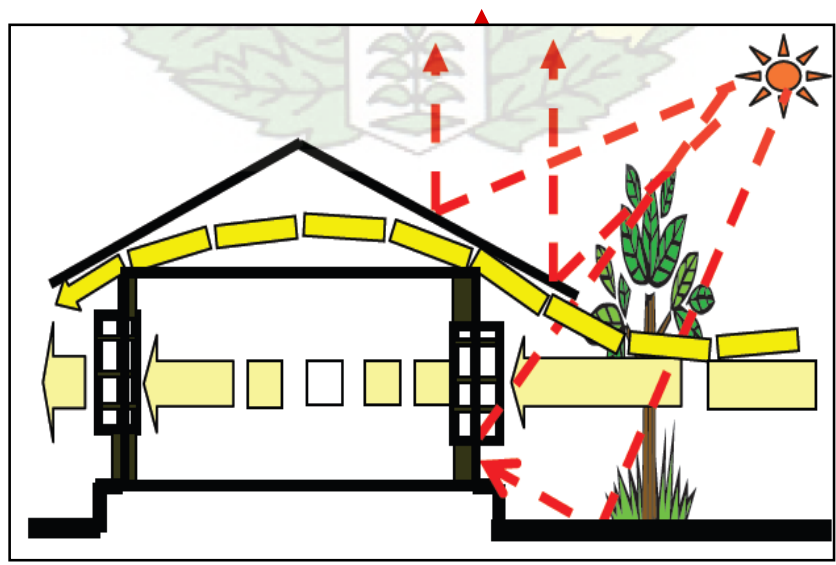

Figure 1. Building's Thermal Control Concept

(Source: Talarosha, B., 2005)

Based on the concept of the building, the materials used need to enable the sunlight to come in through without excessive heating inside the building. One of the materials that matches with the criteria stated above is double glass window which is a glass that is a combination of 2 glass panels with space in 
between panels and also soundproofing materials that are suitable for music purpose buildings and also temperature-resistant so that the room's temperature can be maintained (Figure 2) (Kessler, 1977).

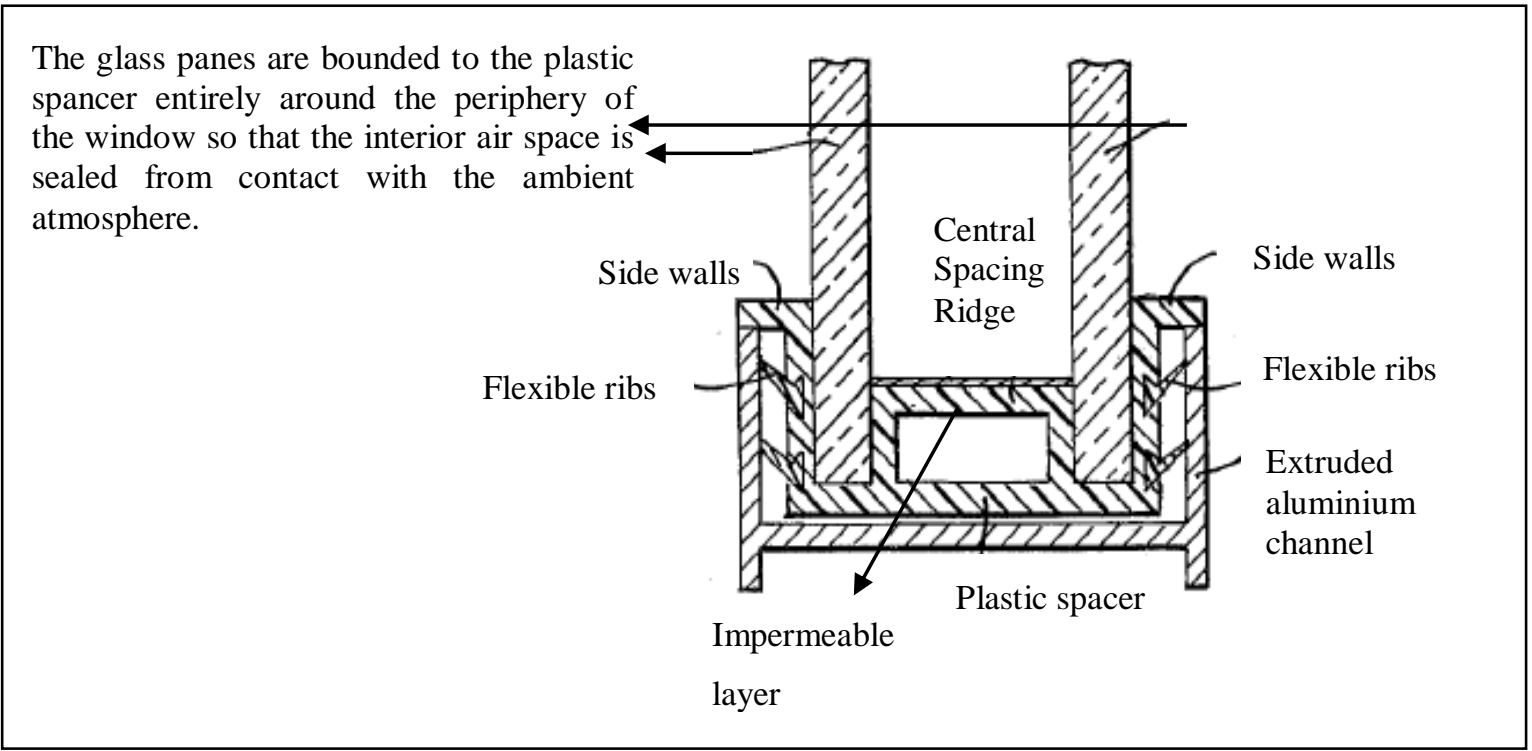

Figure 2. Double Glass System

(Source: Kessler, G., 1977)

The building is a 5-story building and has a basement, so a truss system is used to solve the structural problem where the main structure consists of columns and beams. To maintain the rigidity of the horizontal load from the truss system, columns and beams are used as a support pole which creates a rigid vertex so that the structural system of the building become rigid (Figure 3) (Frick \& Purwanto, 1988).

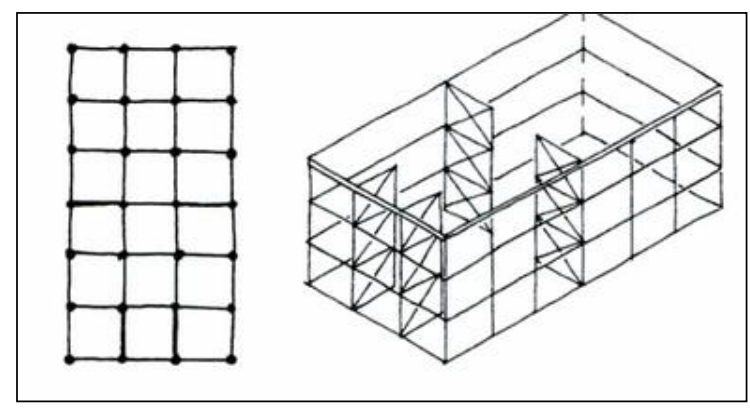

Figure 3. Rigid Frame System

(Source: Frick, I. H., \& Purwanto, L. M. F., 1998)

The clean water supply system uses the general system with the source of the clean water comes from a water supply company.
Meanwhile, the dirty water using filtered tanks to separate the waste, then it will be forwarded to the city drainage (Poerbo, 1992). As for wastewater as part of dirty water distribution system in this building will be reused using Sewage Treatment Plant (STP) system. The process of STP consists of a screen chamber, equalization tank, aeration tank, sedimentation tank, chlorination tank, sludge tank, blower room and effluent tank [14]. Besides that, the rainwater through the Rainwater Harvesting System $(\mathrm{PAH})$ will be reused as clean water. This system is applied to conserve water resources and will be used for watering plant or flushing (figure 4) (Jamwal \& Mittal, 2010).

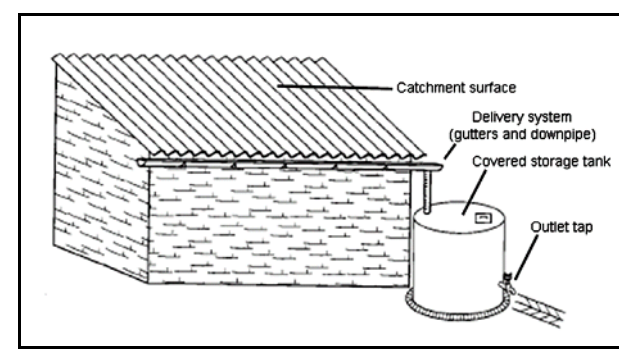

Figure 4. Rainwater Harvesting System (Source: Sturm, 2009) 
Electrical installations consist of several parts such as lighting, electrical outlets, and power. These panels are connected through one main panel which is then connected to the subpanel located on each floor of the building (Figure 5) (Yulistyorini, 2011). The source of the electrical system in the building is from State Electricity Company, as to anticipate the outages of light, a generator is needed for temporary lighting in this building (Poerbo, 1992). An additional source of electrical energy comes from solar energy collected by solar panels which are then converted into electrical energy for the building (Figure 6) (Poerbo, 1992).

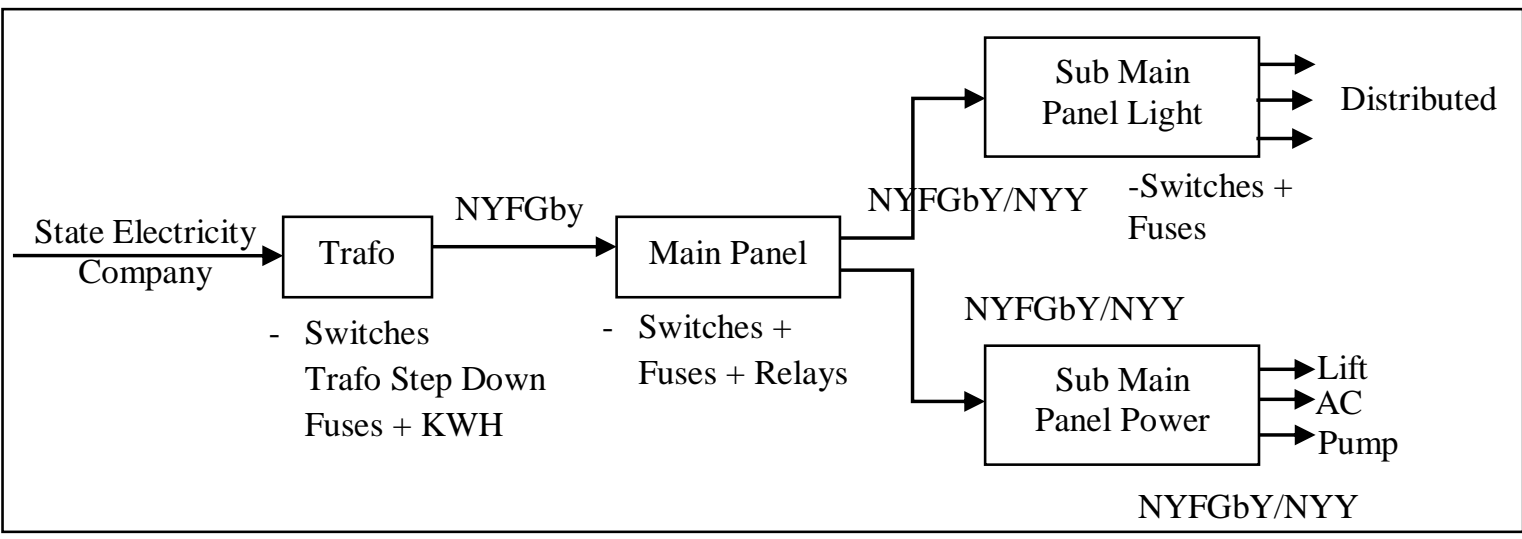

Figure 5. Electrical Distribution System

(Source: Sturm, 2009)

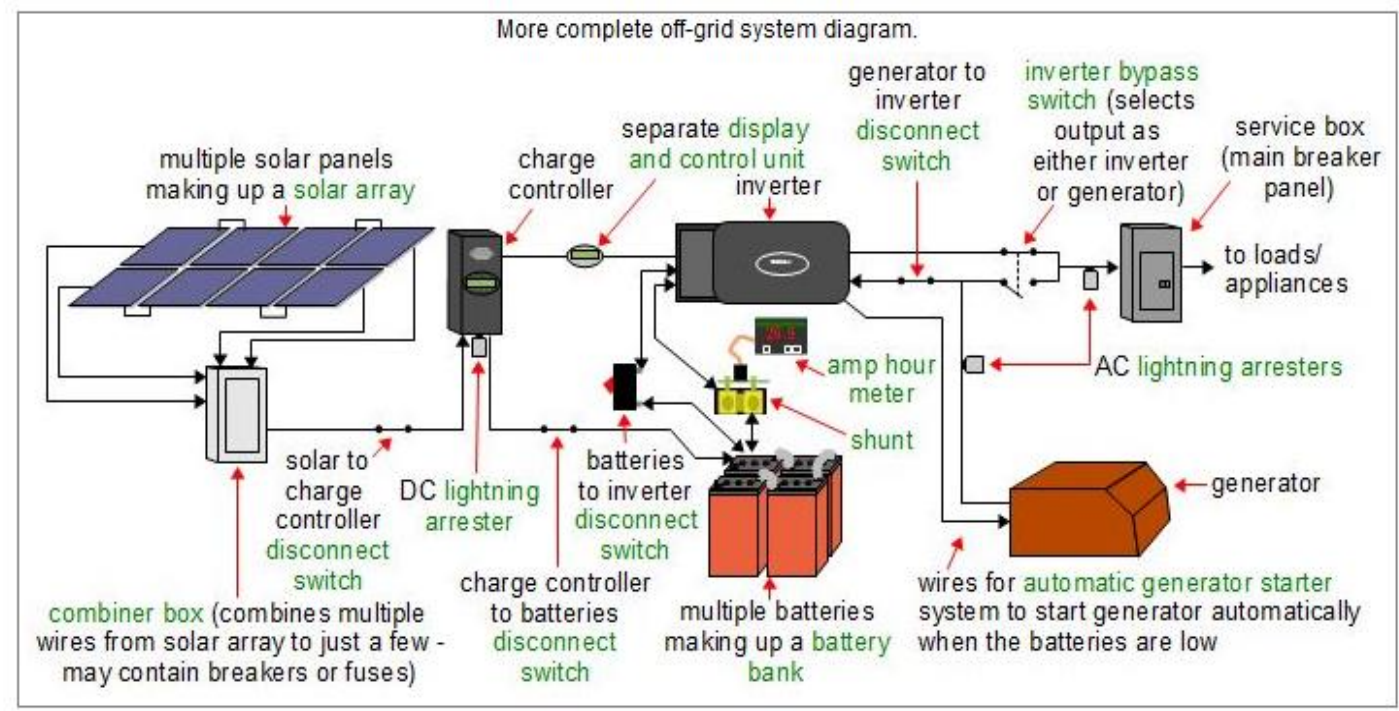

Figure 6. Solar Panel System

(Source: rimstar.org, product knowledge, accessed in August 2018)

\section{METHOD}

The architectural and non -architectural design stages are carried out by analyzing through various libraries and media as a consideration in solving design problems which will include basic concept, site plan concept, circulation concept, the concept of mass composition, structures, and utility concept. The final stage of the design will be poured into the detail of the plan, sections, views, and perspectives of both the exterior and interior of the building.

The reference for design site selection is based on the General Spatial Plan of Medan (RUTRK Medan). Based on the spatial plan of 
the area, the design location is an area directed as a residential area, office, golf course, and urban forest area. This location is suitable as a design location as it is a residential area and also an area which will be developed into a city forest, following the concept of green architecture to be part of the supporting the city's green area.

\section{RESULTS AND DISCUSSION}

Green architecture can be implemented in the design of the music center building. The effectiveness of the studying process is related to the environment of the study place. The purpose if the implementation of green architecture in this music center is to create a natural, comfortable and tranquil environment both in and outside of the building.

\section{Site Plan}

The front area of the site is functioned as a circulation path and also for parking area so that the activities inside of the building are not disturbed and also because it coincides directly with the main access to the site. While the rear area of the building is used for service area such as for STP function and utility and also for an active green open area which is used for the smoking area too (Figure 7).

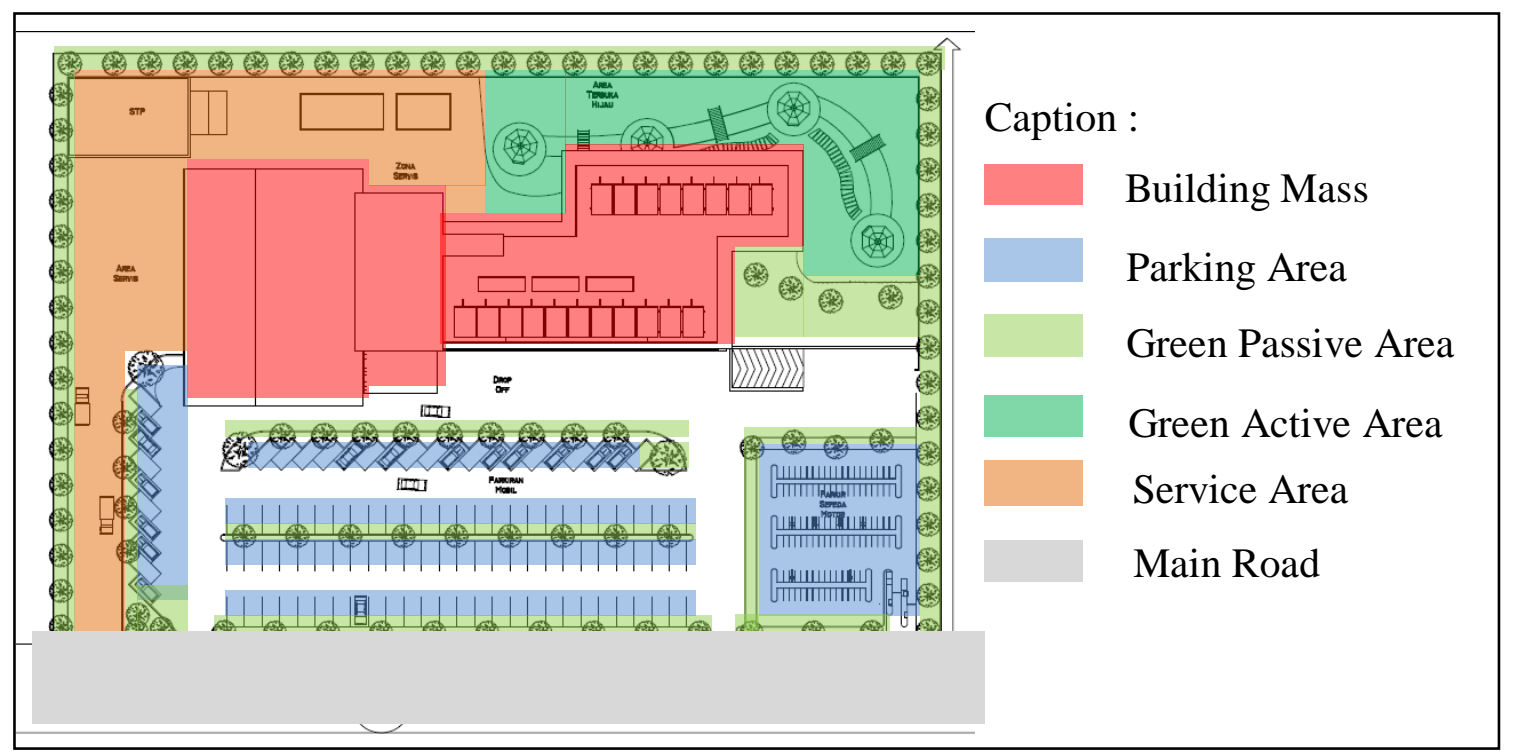

Figure 7. Siteplan Design

\section{Circulation}

There is only one main road for the access into the site and the road is included in the category of secondary arterial roads according to RUTRK Medan and the site is also located in the downtown area to facilitate access to the site (Figure 8).

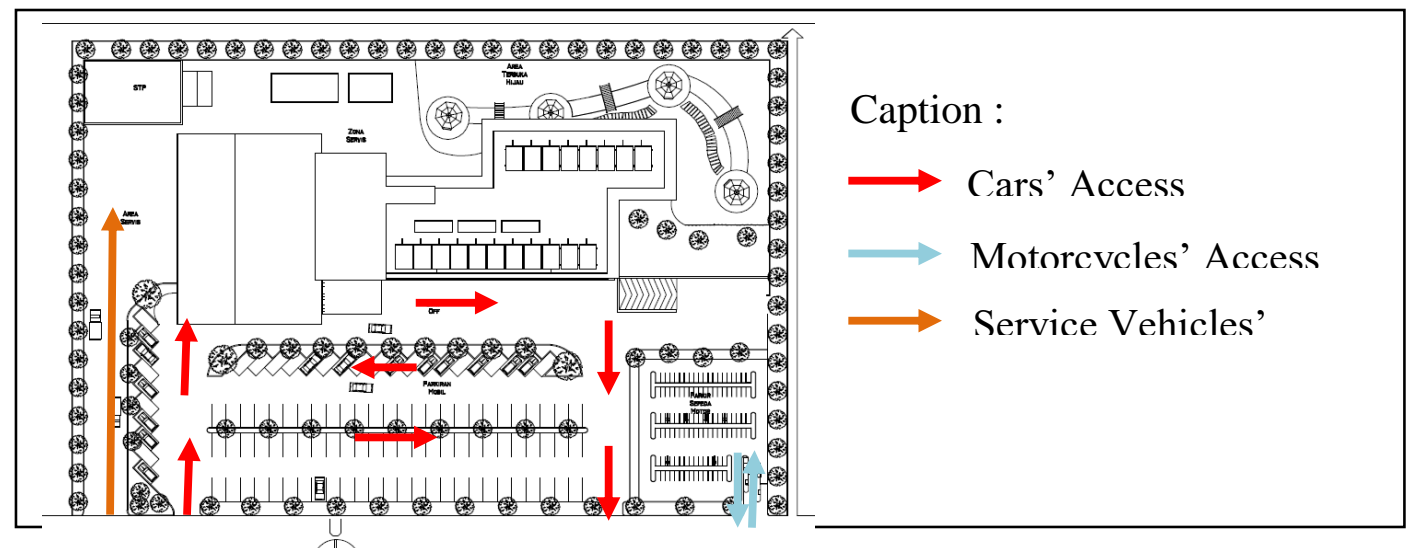

Figure 8. Circulation Concept 
Circulation for vehicles is located in the front area of the site where the access for service vehicles, motorcycles, cars, and pedestrians are designed along the main road with separate access so that the crossing between the vehicles will not occur. Vehicle circulation is designed to circulate the front area of the site. Motorcycle parking is located outside of the building, as for the car parking area is divided into outdoor parking and basement parking area.

\section{Mass Composition}

The mass of the building is set a little to the back to avoid the noise generated by vehicles on the road. The mass of the building is elongated based on the site which is west-east. Beside that, this orientation towards the south also matches with the concept of the building where solar panel technology will be used. This orientation is effective for the solar panel because of the intensity of the sun's radiation is more optimal (Figure 9).

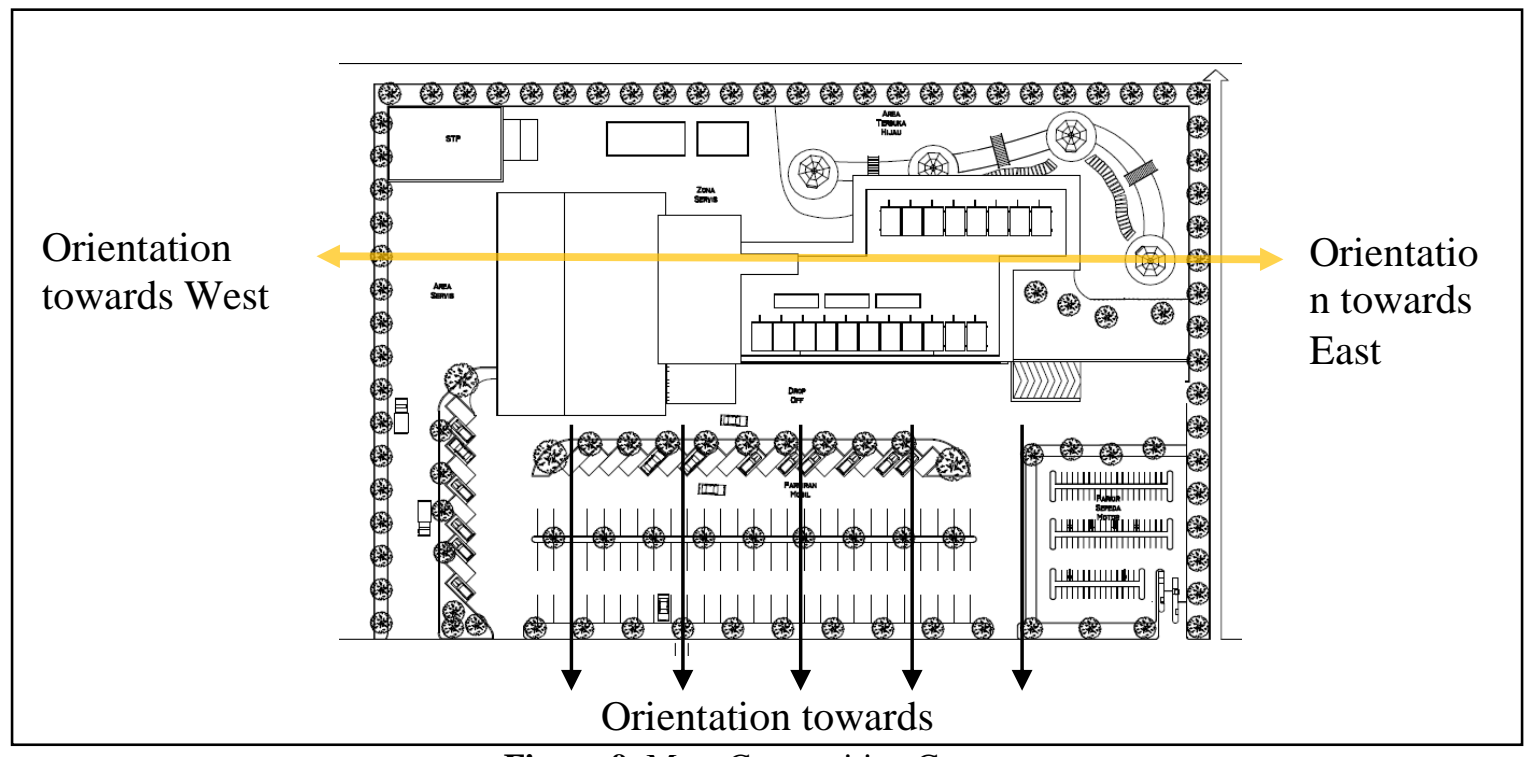

Figure 9. Mass Composition Concept

\section{Inner Space}

The concept of inner space in the building is determined based on its function. The basement floor is used for parking purpose; the administrative and public functions are located on the 1 st floor of the building. The education area is located from the 2nd floor until 4th floor with cluster concept where the classrooms for each type of music are separated and have their corridors. In addition, the distribution of the musical instruments is based on the function of each floor where the 2nd floor is used for theoretical classes and children's music classes, the 3rd floor is used for the musical instrument classes which are more dominant among the male students while the 4th floor is used for the musical instrument classes which are more dominant among the female students.

As for the auditorium building, the 1st floor consists of reception room, and rehearsal room as the 2 nd floor is functioned as the stage room. In the center of the building, a void is designed for lighting and air circulation purpose for the corridor area from the roof and outside of the building (Figure 10). 


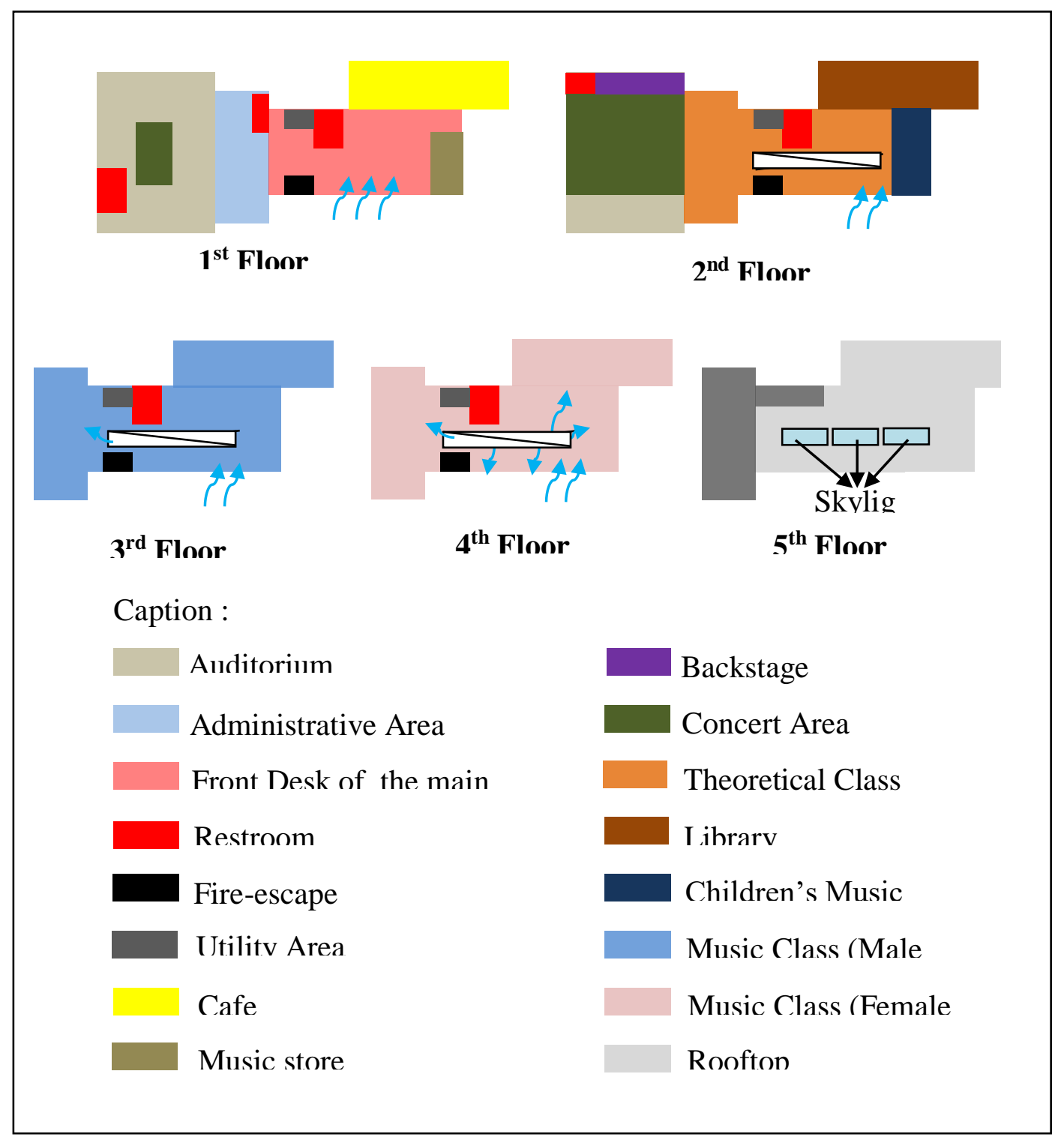

Figure 10. The Concept of Inner Space

\section{Structure}

The structure concept of the building that will be used is the grid system. The material used for the structure is concrete. The structure used is grid pattern with a rigid connection so that the vertical and horizontal fields are formed. A grid pattern is used because the building is an educational building where each of the floors is divided into several classrooms, so the grid system is more efficient for the division of each classroom. Meanwhile, the auditorium uses a wide span structure where the roof structure uses the space frame system (Figure 11).

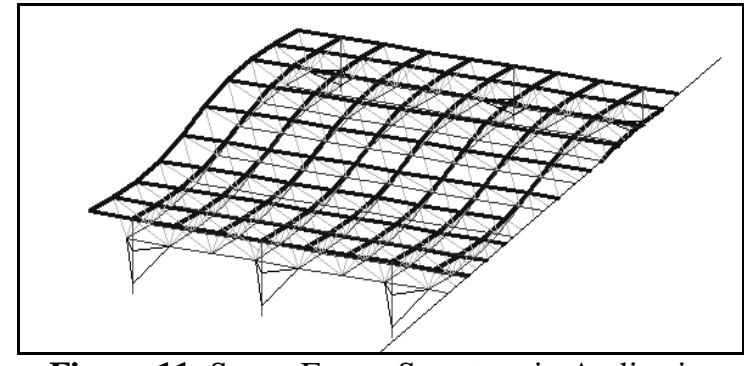

Figure 11. Space Frame Structure in Auditorium

\section{Utility}

The utility concept includes the concept of clean water supply system, dirty water management, rainwater system, and electrical system. The source of clean water is from a water supply company. The clean water 
distribution system used is down feed system which is a system where clean water from the source is housed in a ground water tank then pumped to the roof water tank and the pumped to each floor of the building. In this building, the grey water produced from the floor drain inlet, and sink will be reused using a recycling process or the Sewage Treatment System (STP) and will be used again for flushing or for watering plants so that water resources are utilized optimally. For Blackwater, using a general drainage system will flow to the septic tank, then deposition by bacteria and flowed into the city drainage.

Rainwater from gutters through filters or recycling process will be reused again for clean water purpose. For filtration and recycling process, the site provides a building for utilities on the rear area of the site. The electrical system in the building is sourced from State Electricity Company, to save electricity sources (energyefficient), solar panels are used. These solar panels are placed on the roof of the building where the electrical energy produced from the conversion of solar energy will be used or stored in a battery then used accordingly depends on the needs of the building.

\section{D Impression}

The result of the design is realized in the site plan, ground plan, interior and exterior perspectives (Figure 12-14).

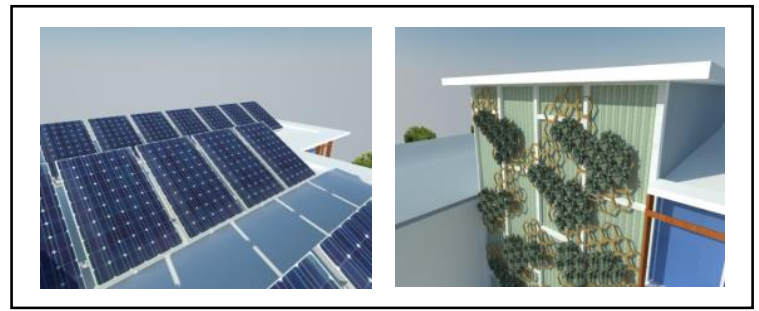

Figure 12. Solar Panel and Vertical Garden

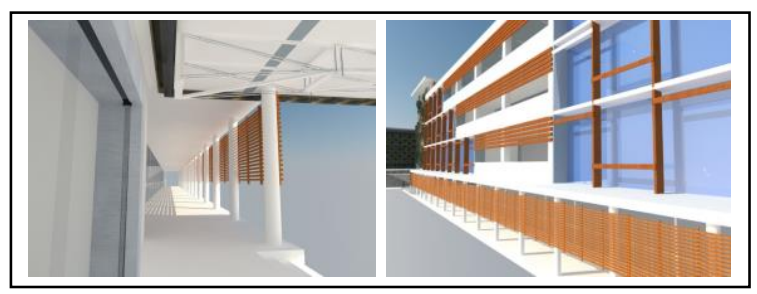

Figure 13. Exterior View

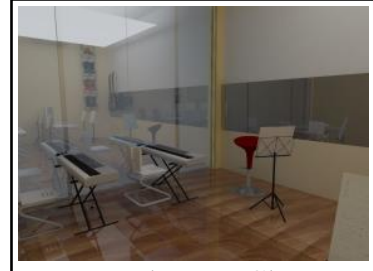

Electone Class.

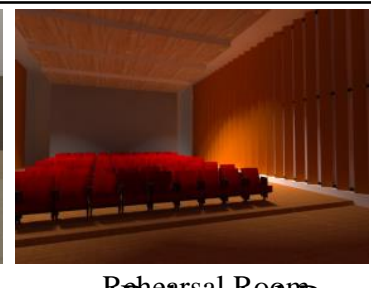

Rehearsal Room
Figure 14. Interior View

\section{CONCLUSION}

The implementation of the green architectural concept in the music center building is done by analyzing the orientation of the building to utilize lighting as well as illuminating solar panels as much as possible, paying attention to the direction of the wind to create natural air circulation in the building so that the use of air conditioners can be minimized, providing an active green area that functions as the smoking area.

With the provision of sufficient parking area, active green area and on-site circulation that is designed in such a way that it does not disturb the users of the building, creating a comfortable outer area so that the quality of the outside and inside spaces can be maintained.

The wastewater which can be reused through Sewage Treatment System for flushing or watering plants, rainwater through the filtration process is also reused. For that function, a building is provided for the utility in the rear area of the site.

\section{Acknowledgment}

This research article was prepared by two researchers who were partially funded by Universitas Sumatera Utara as a contribution to the city government in energy-efficiency planning and design to maintain the existing local wisdom.

\section{REFERENCE}

Darmawan, E. (2007) Peranan Ruang Publik Dalam Perancangan Kota.

Frick, I. H., \& Purwanto, L. M. F. (1988) in Konstruksi Arsitek 1 SISTEM BENTUK STRUKTUR BANGUNAN. 
Dasar-Dasar Konstruksi Arsitektur (Vol. 1), Kanisius.

Jamwal, P., \& Mittal, A. K., (2010) Reuse of Treated Sewage In Delhi City: Microbial Evaluation of Stps and Reuse Options. Resources, Conservation and Recycling.

Karyono, T. H. (2004) Bangunan Hemat Energi: Rancangan Pasif Dan Aktif. Harian Kompas, 31.

Karyono, T. H. (2010) Green Architecture: Pengantar Pemahaman Arsitektur Hijau di Indonesia. Rajawali Pers.

Kessler, G. (1977) Double-Insulated Glass Window with Insulating Spacer. Washington, DC Patent U.S. Patent No. 4,015,394.

Magfirah, U., \& Rachmawati, M. A. (2010) Hubungan Antara Iklim Sekolah Dengan Kecenderungan Perilaku Bullying. Jurnal Universitas Islam Indonesia.

Neufert, E., \& Tjahjadi, S. (2002) Data Arsitek Jilid 1 Edisi 33. Jakarta: Erlangga.

Poerwadarminta, W. J. S. (2008) Kamus Besar Bahasa Indonesia: Pusat Bahasa. Jakarta: Gramedia Pustaka Utama.

Poerbo, H. (1992) in Utilitas Bangunan. Jakarta: Penerbit Djambatan.

Talarosha, B. (2005) Menciptakan Kenyamanan Thermal Dalam Bangunan. Jurnal Sistem Teknik Industri, 6(3).

Vale, B., \& Vale, R (1991) Green architecture: Design for A Sustainable Future. London: Thames and Hudson.
Yulistyorini, A. (2011) Pemanenan Air Hujan Sebagai Alternatif Pengelolaan Sumber Daya Air di Perkotaan. Teknologi dan Kejuruan. 